\title{
FAMILY LEGAL PROTECTION AGAINST DOMESTIC VIOLENCE - PROTECTIVE MEASURES AND SOME PROCESSUAL ASPECTS OF THE PROCEDURE
}

\begin{abstract}
Domestic violence is a widespread and deeply rooted social problem. With the aim of stopping violence and preventing further manifestations of domestic violence, the Family Law prescribes protection measures, but also a special procedure for protection against domestic violence. The goal of this paper is to analyze some processual aspects of this procedure and the challenges that the courts are faced, especially as regards the beginning of the procedure, i.e. a legal nature of lawsuits for protection against domestic violence, a special urgency of the procedure and deviations from the principle of disposition, as well as the measures for protection against domestic violence and the criteria by which the court is guided in the procedure of their passing.
\end{abstract}

Keywords: the measures for protection against domestic violence, a procedure for protection against domestic violence, the court practice

\section{Introduction}

Domestic violence is a harmful and dangerous social phenomenon and, as theory states, "the factor of weakening the family and society as a whole" (Ponjavić, 2012, p. 146). By the Family Law (2005) by the general provision

\footnotetext{
* LLD., Assistant Professor at the Faculty of Law, The University of Kragujevac, Serbia, e-mail: scorac@jura.kg.ac.rs

(c) () (C) 2021 by the authors. This article is an open access article distributed under the terms and conditions of the Creative Commons Attribution (CC BY) license (https://creativecommons. org/licenses/by/4.0/).
} 
of Art. 10 para.1, a ban on domestic violence was established, while para. 2 of this article stipulates that everyone has, in accordance with the law, the right to protection from domestic violence. The provision of Art. 197 of the Family Law (2005) domestic violence is defined as behavior by which one family member endangers the physical integrity, mental health or tranquility of another family member (para. 1). ${ }^{1}$ The Family Law also states exhaustively who is considered a family member and thus determines who can commit an act of domestic violence and according to whom that act can be committed. ${ }^{2}$ By the same method, numerus clausus, all measures that can be imposed in order to protect against domestic violence are listed (Family Law, 2005, Art. 198, para. 2).

In addition to the above substantive provisions in the part of the Family Law (2005) titled "Protection from Domestic Violence" (Art. 197-200), this law constitutes a special procedure - the procedure in a dispute for protection from domestic violence (Art. 283-289), i.e. prescribes procedural provisions. Their basic characteristic is the specifics of accepted procedural principles, that is deviations from the classical principles of general litigation procedure, but also the manner of their operationalization, and it represents a certain challenge for courts in conducting procedures in a dispute for protection from domestic violence.

\section{Procedure in a dispute for protection against domestic violence}

In order to provide a higher level of protection to family members endangered by violence, but also to the family itself, the Family Law (2005), as stated, regulates a special litigation procedure in a dispute for protection against domestic violence. This procedure is based on the modified principles

\footnotetext{
1 The Family Law, in Art. 197 para 2, prescribes that domestic violence is considered in particular: 1. causing or attempting to inflict bodily harm; 2 . causing fear by threatening to murder or inflict bodily harm on a family member or a person close to them; 3 . coercion into sexual intercourse; 4. inducing sexual intercourse or sexual intercourse with a person under the age of 14 or an incapacitated person; 5 . restriction of freedom of movement or communication with third parties; 6. insult, as well as any other insolent, reckless and malicious behavior.

${ }^{2}$ Family members are considered to be spouses or ex-spouses; children, parents and other blood relatives, and in-laws or adoptive relatives, that is, persons bound by foster care; persons living or who have lived in the same family household; extramarital partners or former extramarital partners; persons who have been or are still in an emotional or sexual relationship with each other, i.e.. who already have a child together or a child on the way, even though they have never lived in the same family household. Family Law, 2005, Art. 197 para. 3.
} 
of civil procedure law and is adjusted to the nature of legal matters which are the subject of protection (Stanković \& Boranijašević, 2020, p. 567). In it, apart from the specific provisions of Art. 283-289, the common rules prescribed for all proceedings in family relations are applied (Family Law, 2005, Art. 201-208, as a general procedure in relation to family relations).

Although we have decided that within this paper we would especially analyze lawsuits out of procedural instruments, and then the principle of special urgency of this procedure and deviations from the principle of disposition, the measures imposed by the court for protection against domestic violence and criteria that guides the court in the procedure of their sentencing require a somewhat broader comment.

\subsection{Measures of protection against domestic violence and criteria which the court is guided by}

The Family Law prescribes the following measures for protection against domestic violence: 1. issuing an eviction order from the family apartment or house, regardless of the right of ownership or lease of real estate; 2. issuing an order for moving into a family apartment or house, regardless of the right of ownership or lease of real estate; 3 . ban on approaching a family member at a certain distance; 4 . ban on access to the area around the place of residence or place of work of a family member; 5. prohibition of further harassment of a family member. Prescribed protection measures can also be imposed cumulative, but the court, when it finds that there is domestic violence, is not authorized to determine any other measure, which temporarily prohibits or restricts the maintaining of personal relations with another family member, except those from Art. 198 of the Family Law. ${ }^{3}$

Measures are imposed in concreto, depending on the circumstances of each individual case, and in proportion to the content, intensity and duration of the manifested violence, that is, when determining the measure of protection against domestic violence, the court will take into account the degree and form of manifested violence. ${ }^{4}$ The purpose of all measures listed by law, besides sanctioning the perpetrators of acts of violence, is to prevent future violence as a way to protect vulnerable family members and prevent

\footnotetext{
${ }^{3}$ In that sense, the court practice is also declares itself, e.g. Judgment of the Supreme Court of Cassation, Rev. 3040/2017 of 27.12.2017.

${ }^{4}$ Judgment of the Court of Appeals in Belgrade, Gž2 60/2015 of 25.02.2015.
} 
the spread of conflict. ${ }^{5}$ According to our court practice, the goal of imposing measures is objective prevention of further manifestations of violent behavior and providing victims of domestic violence with peace and tranquility for a certain period of time, ${ }^{6}$ and for non-compliance with these measures, criminal liability is envisaged. ${ }^{7}$ The measure of protection against domestic violence may last for a maximum of one year (Family Law, 2005, Art. 198 para. 3), and may be extended until the reasons for which the measure was imposed cease to exist (Family Law, 2005, Art. 199). If the reasons for which the measure was imposed cease to exist, it may end before the duration has expired (Family Law, 2005, Art. 200). Therefore, the protection provided by the court in the procedure in the dispute for protection against domestic violence consists of imposing a measure for protection against domestic violence, extension of the duration of the imposed measure and termination of the imposed measure.

According to the manner of standardization of Art. 197 of the Family Law, listing the characteristic types of domestic violence actually enables a comprehensive approach, that is, coverage of all possible types of violence, i.e. any insolent, reckless and malicious behavior that endangers the basic values of the human being - his physical integrity, mental health and tranquility. Such a broad definition of the concept of domestic violence, according to court practice, is necessary in order to enable a timely reaction of the system's institutions to domestic violence, i.e. determining the measure of protection against domestic violence while it has not yet taken more severe forms, because this may interrupt the process of escalation of violence. ${ }^{8}$ Insolence, recklessness and malice are components of domestic violence, its essential features, which clearly distinguish it from permissible behavior. These terms represent typical legal standards, the content of which the court should fill with its own judgment. In order for the criteria for concretization of these legal standards to lead to an adequate and timely response to violence in order to prevent it, it is necessary for the court to show a "zero tolerance policy" for violence, which means that any behavior that deviates from the standard of

\footnotetext{
${ }^{5}$ For example, Decision of the Court of Appeals in Novi Sad, Gž2 601/2016 of 28.07.2016.; Judgment of the Supreme Court of Cassation, Rev. 2249/2016 of 15.12.2016; Judgment of the Supreme Court of Cassation, Rev.3629/2018 of 21.6.2018.

6 Judgment of the Supreme Court of Cassation, Rev. 1169/2016 of 13.07.2016.

7 The Criminal Code, 2005, Art. 194, para. 5, prescribes a special basis for criminal responsibility, that is, prescribes that whoever violates the measures of protection against domestic violence determined by the court on the basis of the law governing family relations, shall be punished by imprisonment of three months to three years and a fine.

${ }^{8}$ Judgment of the Supreme Court of Cassation, Rev. 3040/2017 of 27.12.2017.
} 
"normal" treatment and communication with family members can be qualified as domestic violence. ${ }^{9}$

The subjective feeling of the victim about the endangerment is also important for initiating the procedure for protection from domestic violence, and in the light of the assessment of the existence of domestic violence and the existence of the need to determine the protection measure. ${ }^{10}$ Therefore, the court evaluates the assessment of the risk and threat of domestic violence in concreto, so the reasoning of one decision states that there is no basis for imposing the measure of protection against domestic violence in a situation where the defendant has taken action against a family member which by nature and by legal definition has the characteristics of domestic violence, but it is situational and represents an incidental event, if such behavior did not occur or recur, neither before nor after the act of violence, and the family member does not feel anxious, uneasy or afraid or threatened in any way. ${ }^{11}$ When, by the court's assessment, it is a matter of subjective experience of violence by the victim, which is not objectified by other acts, e.g. "only" the addressing of abusive words by the defendant to the plaintiff at the moment when the defendant suspected that the plaintiff had an emotional partner, which is an isolated event which was not preceded, nor did such inappropriate behavior by the defendant continue, with no acts of physical violence between the parties, the court considers that the claim should be rejected, i.e. that there is no place for imposing measures for protection against domestic violence. ${ }^{12}$ However, in the absence of an act that could be considered domestic violence by law, there are no conditions for imposing proposed protection measures, despite the existence of dysfunctional family relations and isolated incidents among family members. ${ }^{13}$

Although there is an undivided view that violence is most often a matter of power and control over the victim, and violent behavior is any intentional act that damages (Milutinović, 2012, p. 17), in theory and court practice there is no agreement on whether violence exists only as pattern of behavior or it may, however, be an individual incident. In other words, the question is whether domestic violence is considered behavior that is necessarily continuous, that is, violence that lasts for some time, or only one act of violence,

\footnotetext{
${ }^{9}$ Judgment of the Supreme Court of Cassation, Rev. 5008/2019 of 12.12.2019.

${ }^{10}$ In this regard the judgment of the Supreme Court of Cassation, Rev. 624/2021 of 03.03.2021.

11 Judgment of the Court of Appeals in Niš, Gž2. 20/2019 of 17.01.2019 - Bulletin of court practice of the High Court in Niš no. 35/2019

12 Judgment of the Supreme Court of Cassation, Rev. 5062/2020 of 25.11.2020.

13 Judgment of the Court of Appeals in Novi Sad, Gž2 368/2016 of 16.06.2016.
} 
so-called incidental violence can be relevant for imposing measures of family protection (Ponjavić \& Palačković, 2012, p. 55). The answer is certainly given by the stance that "in some situations in family life, a single act will be qualified as violent, while in other circumstances and occasions, an insult spoken multiple times to a family member may be insufficient to determine the state of endangerment of physical integrity, mental health and tranquility of another family member and to determine some of the protective measures (Draškić, 2008, p. 346). In that sense, in theory it is stated that one act of violence is relevant, unless especially mitigating circumstances (impulsiveness contrary to the character of the perpetrator, stressful life moment, irritating and impermissible behavior of the victim of violence) justify the legal relevance of continuous behavior (Panov, 2010, p. 375). In a word, it depends on the specific case whether individual violence will be characterized as domestic violence or an established model of behavior of a person that is of such importance that it requires the provision of legal protection. ${ }^{14}$

\subsection{Initiation of procedure in a dispute for protection against domestic violence}

The reason for initiating proceedings in a dispute for protection from domestic violence is a deviation from the standard of normal and civilized behavior of a family member, who by such behavior, violence, violates the physical integrity, mental health and tranquility of another family member, as already mentioned. The degree and form of the manifested violence are always important for the court when deciding on the qualification that the violence has occurred as well as when imposing one of the possible protection measures. ${ }^{15}$ As the Family Law also lists family members between whom violence is possible, in practice there are difficulties in proving the emotional or sexual relationship, that is, other personal relationship to which a person seeking protection from domestic violence refers, which is also indicated in theory (Ponjavić \& Vlašković, 2019, p. 464).

The procedure for imposing a measure in a dispute for protection against domestic violence is initiated by a lawsuit. The actively legitimized are family member/members against whom the violence was committed, but a lawsuit can certainly be filed on their behalf by a legal representative in case of lack of legal capacity, but the public prosecutor and the guardianship authority also

\footnotetext{
${ }^{14}$ In this regard the judgment of the Supreme Court of Cassation, Rev. 4775/2019 of 28.11.2019.

15 Judgment of the Court of Appeals in Belgrade, Gž2. 60/2015 of 25.2.2015.
} 
have legitimacy under the Family Law (Family Law, 2005, Art. 284, para. 2). This solution is certainly a consequence of the generally accepted attitude that domestic violence is a serious social problem, and not a private matter of individuals, that is, that public interests are protected through the protection of individuals and families. In theory, it is emphasized that the extreme sensitivity of this procedure, which should provide protection to victims of domestic violence even without her initiative, conditioned the extension of the right to a lawsuit for protection from domestic violence to some state authorities, because a family member could find themselves in a situation where, due to fear of the perpetrator, they do not initiate court proceedings at all or reluctantly give up under the pressure of the perpetrator of domestic violence (Draškić, 2016, p. 629). The procedure for extending the measure of protection against domestic violence is also initiated by a lawsuit, and all the aforementioned entities are actively legitimized. The Family Law prescribes, as stated, the procedure for termination of the imposed measure, which is also initiated by a lawsuit, which can be filed only by a family member against whom the measure is determined if the reasons cease to exist (Family Law, 2005, Art. 284, para. 3).

The Family Law does not prescribe the form and content of the lawsuit, but the provisions of the law governing civil proceedings apply to the court proceedings related to family relations (Family Law, 2005, Art. 202).$^{16}$ In addition to the general elements that each lawsuit must contain (designation of the court, parties and representatives and the subject matter of the dispute), the lawsuit initiating the procedure for imposing a measure / and in a dispute for protection against domestic violence must also contain data or evidence that they are victims and the bully are family members, a description of the event - actions and behaviors by which the violence was committed, as well as evidence that such action, that is, behavior was committed or a proposal to present evidence of the stated circumstances (Radaković, 2016, p. 38). The central part of the lawsuit for protection against domestic violence, as usual, is the claim, which must be precisely and clearly defined. In the subjective sense it means that the entity - the defendant against whom the determination of one or more measures of protection against domestic violence is requested and the entity - victim for whose protection the determination of the measure/measures for protection against domestic violence is requested, must be labeled,

\footnotetext{
${ }^{16}$ In that sense, the lawsuit must contain all those elements prescribed by the Law on Civil Procedure (Official Gazette of RS, No. 72/2011, 49/2013 - decision of the US, 74/2013 - decision of the US, 55/2014, 87/2018 and 18/2020), Art. 192 para. 1, i.e. Art. 98.
} 
while in the objective sense, it means the designation of the measure/measures of protection against domestic violence whose determination is required, as well as the length of their duration (Radaković, 2016, p. 38). Although the basic postulate of civil litigation procedure is that the claim must be "specified" (Poznić \& Rakić-Vodinelić, 2015, p. 309), concrete, which in the procedure for protection against domestic violence would mean that the plaintiff must determine one or more measures from the Family Law, which the court should pronounce by judgment if it concludes that the request is grounded, and the Family Law explicitly stipulates in Art. 287, para. 2 that the court may also impose a measure of protection (or more such measures) from domestic violence that is not requested if it assesses that such measure achieves better protection (in that sense, Draškić, 2016, p. 631). Such legal solution is conditioned by the fact that the court assesses the circumstances of the case in concreto, then the validity of the investigative maxim, as well as the emphasized formality and limited disposition of the parties. In practice, we find the position of the Supreme Court of Cassation which considers that a lawsuit to establish the existence of domestic violence, which does not contain a request for determining an appropriate protection measure, is allowed, because in a dispute for protection from domestic violence before determining a measure of protection from domestic violence it is always pre-examined and determined whether violence has been committed. ${ }^{17}$ This would mean that, in the conditions of the court's non-binding to the limits of the claim, it can also impose a protection measure on the basis of a declarative lawsuit, therefore, as if a condemnatory lawsuit had been filed. A victim of domestic violence can file a lawsuit asking the court to order a temporary measure, which is not often used in practice.

A lawsuit for protection against domestic violence is, according to the position expressed in our theory, both constitutive and condemnatory in its legal nature (Stanković \& Boranijašević, 2020, p. 568; Petrušić, 2006, p. 40; Radaković, 2016, p. 38). The dual legal nature of this lawsuit is a consequence of, on the one hand imposing a legal change, which is a characteristic of constitutive (transformational) lawsuits, while on the other hand, the obligation to do or not do through imposing a protection measure indicates a condemnatory character. The constitutive element is reflected in the request for the court to pronounce a certain change, the essence of which, regardless of the type of measure, is to prohibit the defendant from exercising a certain right or behavior and thus introduce a change in the existing relations of the parties, while the condemnatory element is reflected in the request for the court pronounces

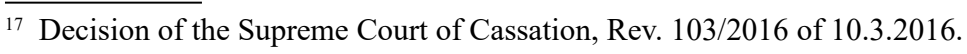


a specific notice to the defendant, i.e. to order him to, in accordance with the pronounced prohibition, do something or to refrain from certain actions (Petrušić \& Konstantinović Vilić, 2010, p. 32-33).

The lawsuit initiating the procedure for extension of the measure has the same character, and this procedure can be initiated successively, an unlimited number of times, until the reasons for which the measure was pronounced cease to exist, which follows from the interpretation of legal norms that do not prescribe restriction in that sense. Analogously, the judgment rendered by the court in these procedures, according to the content of the legal protection provided, has a condemnatory and constitutive character, i.e. "it is a mixed, constitutive - condemnatory judgment" (Poznić \& Rakić-Vodinelić, 2015, p. 436). The operative part of the judgment states which measure(s) the court imposes, the duration of the measure(s), the distance in meters in the measure prohibiting the perpetrator from approaching the victim at a certain distance, the exact place of work or residence in the pronouncing of the measure which prohibits the perpetrator from accessing the place of residence and/or work place. According to the explicit legal provision, the appeal does not delay the execution of the judgment on determining or extending the measure of protection against domestic violence (Family Law, 2005, Art. 288), i.e. the judgment by which the court pronounced the measure(s) for protection against domestic violence may be executed even before the validity of that decision, which is certainly a specificity that should be mentioned.

\subsection{Special urgency of the procedure}

A special rule prescribed for the procedure in family relations, which refers to urgency, is certainly applied in this procedure as well, with the aim of preventing further escalation of violence. In principle, the rule of urgency in family disputes is realized by not submitting the lawsuit to the defendant for response and the procedure is conducted at a maximum of two hearings if it refers to a child or parent exercising parental rights (Family Law, 2005, Art. 204, para. 1 and 3). However, the Family Law additionally operationalizes the procedure in the dispute for protection against domestic violence with a special rule and prescribes special urgency (Family Law, 2005, Art. 285) and due to the need for urgent protection of the victim of domestic violence. The first hearing is scheduled to take place within eight days from the day when the lawsuit was received in court, and the second instance court is obliged to make a decision within 15 days from the day when the appeal was submitted to it (Family Law, 2005, Art. 285 para. 2 and 3), that is, files of legal matters by the first instance 
court. Prescribed short deadlines should lead to court efficiency and immediate protection of victims of violence. However, the Family Law does not prescribe how much time should elapse between hearings, nor the total period in which this procedure should be completed, but the general rules from Art. 10 para. 2 of the Law on Civil Procedure (2011) on the time frame of litigation apply, which presupposes that the court implements the special urgency through the decision on the time frame of the litigation. In addition, the problem is the postponement of the hearing for various reasons (e.g. impediment or absence of a judge, absence of witnesses, expert witness or experts from the Center for Social Work, failure of this body to deliver an opinion on the appropriateness of protection against domestic violence, failure to submit findings and expert opinions, elimination of assessed deficiencies, etc.), followed by a new decision on the time frame, which all points to insufficient guarantees of the special urgency of the court's actions. In other words, although the legislator's diction regarding the special urgency of this procedure is clear, the victim of violence is not provided with any special certainty regarding the length of this procedure after the initiated procedure before the court. In addition, the fact that the court in this procedure walks a thin line should not be neglected, because on the one hand it is required to be diligent in preparing procedural materials in order to conduct the procedure in the smallest possible time frame, while on the other hand, the duty to act with special urgency regarding the request for protection from domestic violence does not authorize the court to refuse presenting of some evidence due to urgency.

\subsection{Deviation from the principle of disposition}

As a rule, subjects of family law relations do not have the freedom to dispose of rights and obligations due to their legal nature. For that reason, the disposition of litigants in the procedure for protection against domestic violence is limited (its initiation, holding within the deadline and termination do not depend only on the will of the parties). That is, in this procedure, the principle of court proceedings prevails over the principle of disposition, and consequently over the investigative principle. That is, in theory, it is more about the limitations in the application of the dispositive maxim and the investigative powers of the court (Draškić, 2016, p. 631).

One of the important deviations from the principle of disposition, which has already been discussed in this paper, is the expansion of the circle of actively legitimized entities, i.e. those who have the right to sue. Apart from the explicitly determined subjects of family law relations in which violence was 
manifested, the right to sue is also recognized to certain entities. Furthermore, the deviation from the principle of disposition is clearly manifested in the court's authority to initiate proceedings for protection against domestic violence ex officio as an adhesion procedure, so this procedure can be conducted as an independent, separate procedure or as an associated procedure, when the court identifies acts that can be characterized as domestic violence and that there is a need for protection.

Furthermore, the court in this procedure has the authority to act outside the limits of the filed claim and is not bound by the proposal of the authorized person regarding the protection measure(s). The court is therefore free to determine the measure of protection (or more such measures) that the plaintiff did not request, if it considers that in that way better protection is achieved for the victim of domestic violence, ${ }^{18}$ which has also already been discussed. In doing so, the court primarily has an active role in determining the existence of violence, by applying the investigative maxim. That is, the court may also establish facts that have not been presented by the parties, and those that are not in dispute between the parties, as well as present evidence that neither party has proposed. This approach can certainly indicate that the measure required by the lawsuit in a specific case cannot be expedient and effective, but that it is necessary to impose another or other measures. ${ }^{19}$ The type of measure depends on the court's assessment of the danger to which the victim is exposed, and which protection measure will be imposed depends on the specific action that constitutes domestic violence, the danger caused by that action, the family member's anxiety, their endangerment and the assessment of the risk of recurrence. In other words, the Family Law does not prescribe any restriction regarding the type and number of measures that the plaintiff may request in the lawsuit, within the limits set by the enumeration of measures, nor a restriction of the court regarding their imposition. The opinion of the victim, but also the subjective feeling, aforementioned in the paper, but also the degree of danger that threatens them, also affects the choice of protection measure that will be determined in a specific case, because, after all, it is the victim who is protected, so subjective assessment of the victim, e.g. based on experience, presents a key factor in choosing the protection measure that will be determined in each specific case. ${ }^{20}$

\footnotetext{
18 Judgment of the Court of Appeals in Novi Sad, Gž2 739/2012 of 3.12. 2012; Judgment of the Supreme Court of Cassation, Rev. 2844/2010 dated 26.05.2010.

19 Decision of the Supreme Court of Cassation, Rev. 103/2016 of 10.3.2016.

20 Judgment of the Supreme Court of Cassation, Rev. 3040/2017 dated 27.12.2017.
} 


\section{Conclusion}

The Family Law establishes a system of family law protection against domestic violence. In order to prevent further manifestations of violence, measures for protection against domestic violence are envisaged, but a special procedure in the dispute for protection against domestic violence has been standardized. The paper analyzes some procedural aspects of this procedure (legal nature of the lawsuit, procedural legitimacy for its filing, particular urgency of the procedure, deviation from the principle of disposition, and in that sense (non)binding of the court to the limits of the claim and the authority of the court to impose a measure/measures for protection against domestic violence even without the request of a party, etc.) and the challenges that courts face in the application of special procedural institutes provided for this procedure in practice.

The analyzed theory and the formed sufficient quantum of court practice give the possibility to conclude about the unison position that the court has "zero tolerance" for violence, about the built criteria that the court is guided by in assessing whether an action is an act of domestic violence, about the need to determine adequate protection measures from domestic violence in each specific case and about the clearly emphasized temporary and preventive protection (which aims to stop further escalation of violence) provided by the court by imposing these measures. In practice, there are no inequalities, that is, uneven interpretation of procedural norms prescribed in the procedure for protection against domestic violence. Still, as stated in the paper, some provisions regulating this procedure have not been fully operationalized, so there is a need for precise standardization of the total duration of this procedure and in that sense elimination of uncertainty for the victim of violence. In addition, the adoption of further individual solutions, apart from the already existing ones, should specify the rules on collecting and presenting evidence of conducted violence, with the idea of preventing delays of the procedure (e.g. unlimited hearing of witnesses), but also rules on a more active role of the court in that sense. That provides an opportunity for consideration of possible directions of development de lege ferenda that would lead to improved protection of this right, through the improvement of existing and implementation of new solutions. 


\section{Acknowledgments}

The paper is the result of research on the project of the Faculty of Law of the University of Kragujevac: "Harmonization of the legal system of Serbia with the standards of the European Union", which is funded by the Faculty.

\section{Corac Sanda}

Docent na Pravnom fakultetu Univerziteta u Kragujevcu, Srbija

\section{PORODIČNOPRAVNA ZAŠTITA OD NASILJA U PORODICI - MERE ZAŠTITE I NEKI PROCESNI ASPEKTI POSTUPKA}

REZIME: Nasilje u porodici je rasprostranjen i duboko ukorenjen društveni problem. Sa ciljem zaustavljanja nasilja i sprečavanja daljeg ispoljavanja nasilja u porodici Porodični zakon propisuje mere zaštite, ali i poseban postupak za zaštitu od nasilja u porodici. Cilj rada je analiziranje nekih procesnih aspekata ovog postupka i izazova sa kojima se susreću sudovi, posebno u odnosu na pokretanje postupka, odnosno pravnoj prirodi tužbi za zaštitu od nasilja u porodici, naročitoj hitnosti postupka i odstupanjima od načela dispozicije, kao i merama za zaštitu od nasilja u porodici i kriterijumima kojima se rukovodi sud u postupku njihovog izricanja.

Ključne reči: mere zaštite od nasilja u porodici, postupak za zaštitu od nasilja u porodici, sudska praksa.

\section{References}

1. Draškić, M. (2008). Nasilje u porodici: prva presuda Vrhovnog suda Srbije [Domestic violence: the first verdict of the Supreme Court of Serbia]. Anali Pravnog fakulteta u Beogradu, 56 (2), pp. 341-351

2. Draškić, M. (2016). Komentar Porodičnog zakona [Commentary on the Family Law]. Beograd: Službeni glasnik

3. Krivični zakonik [Criminal Code]. Službeni glasnik $R S$, br. 85/05, 88/05 ispr., 107/05 - ispr., 72/09, 111/09, 121/12, 104/13, 108/14, 94/16 i 35/19 
4. Milutinović, Lj. (2012). Nasilje u porodici [Domestic violence]. Pravni informator, 15 (6), pp. 16-19

5. Panov, S. (2010). Porodično pravo [Family law]. Beograd: Službeni glasnik

6. Petrušić, N. \& Konstantinović Vilić, S. (2010). Porodičnopravna zaštita od nasilja u porodici u pravosudnoj praksi Srbije [Family law protection from domestic violence in the judicial practice of Serbia]. Beograd: Autonomni ženski centar; Niš: Ženski istraživački centar za edukaciju i komunikaciju

7. Petrušić, N. (2006). Porodičnopravna zaštita od nasilja u porodici [Family law protection from domestic violence]. In: Ponjavić, Z. (ed.), Novo porodično zakonodavstvo: zbornik sa savetovanja [New Family Legislation: Proceedings of the Conference] (pp. 21-47). Kragujevac: Pravni fakultet, Centar za porodično pravo

8. Ponjavić, Z. \& Palačković, D. (2012). Prekogranično odvođenje dece i porodično nasilje [Cross-border child abduction and domestic violence]. In: Marković, G. (ed.), Prava djeteta i ravnopravnost polova - između normativnog i stvarnog: zbornik radova [Children's rights and gender equality - between the normative and the real: a collection of papers] (pp. 47-71). Pale - Istočno Sarajevo: Pravni fakultet Univerziteta u Istočnom Sarajevu

9. Ponjavić, Z. \& Vlašković, V. (2019). Porodično pravo [Family law]. Beograd: Službeni glasnik

10. Ponjavić, Z. (2012). Odgovornost države za nasilje u porodici prema Konvenciji o ljudskim pravima [State responsibility for domestic violence under the Convention on Human Rights]. In: Panov, S., Janjić Komar, M., Škilić, M. (eds.), Nasilje u porodici: zbornik radova sa naučnog skupa [Domestic violence: a collection of papers from a scientific conference] (pp. 146-163). Beograd: Pravni fakultet Univerziteta, Centar za izdavaštvo i informisanje

11. Porodični zakon [Family law]. Službeni glasnik $R S$, br. 18/05, 72/11 - dr. zakon i $6 / 15$

12. Poznić, B. \& Rakić-Vodinelić, V. (2015). Građansko procesno pravo [Civil procedural law]. Beograd: Pravni fakultet Univerziteta Union

13. Radaković, S. (2016). Tužba i presuda u postupku radi zaštite od nasilja u porodici po Porodičnom zakonu, Pravni informator, 19 (11), pp. 38-40

14. Stanković, G. \& Boranijašević, V. (2020). Građansko procesno pravo [Civil procedural law]. Niš: Sven

15. Zakon o parničnom postupku [Law on Civil Procedure]. Službeni glasnik $R S$, br. 72/11, 49/13 - odluka US, 74/13 - odluka US, 55/14, 87/18 i $18 / 20$ 